\title{
ASSESSMENT OF THE STRENGTH OF FOUNDATION MATERIALS IN SOME PARTS OF AFIKPO, NIGERIA USING SEISMIC REFRACTION METHOD
}

\author{
S. O. Agha * A. E. Akpan, ${ }^{+* *}$ and E. E. Okwueze ${ }^{+}$ \\ *Department of Industrial Physics \\ Ebonyi State University, Abakaliki, Nigeria \\ ${ }^{+}$Physics Department, University of Calabar, Calabar, Nigeria
}

(Submitted: 2 August, 2005; Accepted, 20 June, 2006)

\begin{abstract}
Seismic refraction field method was carried out in five communities in Afikpo located between latitudes $5^{\circ} 52^{I} N$ and $5^{\circ} 57^{I} N$ and longitudes $7^{\circ} 52^{I} E$ and $7^{\circ} 58^{I} E$ using a 3 channel digital type signal enhancement seismograph to determine the strength offoundation materials. Results from the 10 sites investigated show that seismic waves from the hammer source penetrated only the first three layers of the earth. Average thickness of $3.6 \mathrm{~m}$ (probably sandy clay) and $11.8 \mathrm{~m}$ (probably gravelly sand) was obtained for the first and second layers respectively. The first and second layers have average Poisson ratio ( $\nu$ ) of 0.16 and 0.28 , average shear modulus $(\mu)$ of $3.54 \times 10^{8}$ and $33.74 \times 10^{8} \mathrm{~N} / \mathrm{m}^{2}$, average bulk modulus $(\mathrm{k})$ of $0.72 \times 10^{9}$ and $15.04 \times 10^{9} \mathrm{~N} / \mathrm{m}^{2}$, average young modulus (E) of $0.82 \times 10^{9}$ and $9.54 \times 10^{9} \mathrm{~N} / \mathrm{m}^{2}$ and average lames constant $(\lambda)$ of $2.52 \times 10^{9}$ and $29.26 \times 10^{9} \mathrm{~N} / \mathrm{m}^{2}$ respectively. These results show that soils in the area are thick, rigid and well consolidated. The soils can withstand stress and as such are suitable for engineering construction work.
\end{abstract}

Key words: Afikpo, foundation materials, modulus, refraction and strength.-To whom all correspondences should be directed.

\subsection{Introduction}

The behaviour of seismic waves travelling in rocks has been a subject of extensive theoretical and experimental investigation since the beginning of the eighteenth century (Mesfin and Moon, 1984). Such researches have yielded results whose workability in most cases is still being tested. Useful relation usually used for describing and characterising the elastic nature of the earth is the stressstrain relation. These relations are well documented in relevant literature (Kearey and Brooks, 1991; Dobrin and Savit, 1988; Ostrander, 1984; Griffiths and King, 1981; Domenico, 1977 and Telford et al., 1976).

In the building/construction industry, elastic behaviour of rocks and their characteristics have been extensively used to test the bearing strength of foundation materials prior to construction work (Okwueze, 1991 and Okwueze, 1988). Presence of lateral and vertical inhomogeneities in the earth makes it impossible for results to be valid outside the study area. This study is a pioneering one directed towards eliciting the strength of foundation materials in some communities in Afikpo, Ebonyi State of Nigeria. Findings will be useful to both private and government agencies involved in building/construction work.

Elastic parameters employed in assessing the strength of foundation materials in this study are bulk modulus $(\mathrm{k})$, shear modulus $(\mu)$, Poisson ratio $(v)$, young modulus $(E)$ and lame constant $(\lambda)$. Their relationship with measurable parameters ( $p$ wave velocity, $s$ wave velocity and rock density) is well 
documented in relevant literature (Dobrin and Savit, 1988; Ostrander, 1984; Griffiths and King, 1981 and Telford et al , 1976).

\subsection{A Brief Geology and Geomorphology of Afikpo}

Afikpo lies between latitudes $5^{\circ} 52^{\prime}$ and $5^{\circ} 57^{\prime} \mathrm{N}$ and longitudes $7^{\circ} 52^{\prime}$ and $7^{\circ} 58^{\prime} \mathrm{E}$ with a total surface area of about $50 \mathrm{~km}^{2}$ (Fig. 1). The entire area that lies south of the Benue Trough has three major geologic units the Albain Asu River Group (Lower Cretaceous), the Turonian Eze Aku Formation and the Nkporo Shale. Each of these geologic units outcrops on the surface and can be seen as one moves from east to west along the study area.

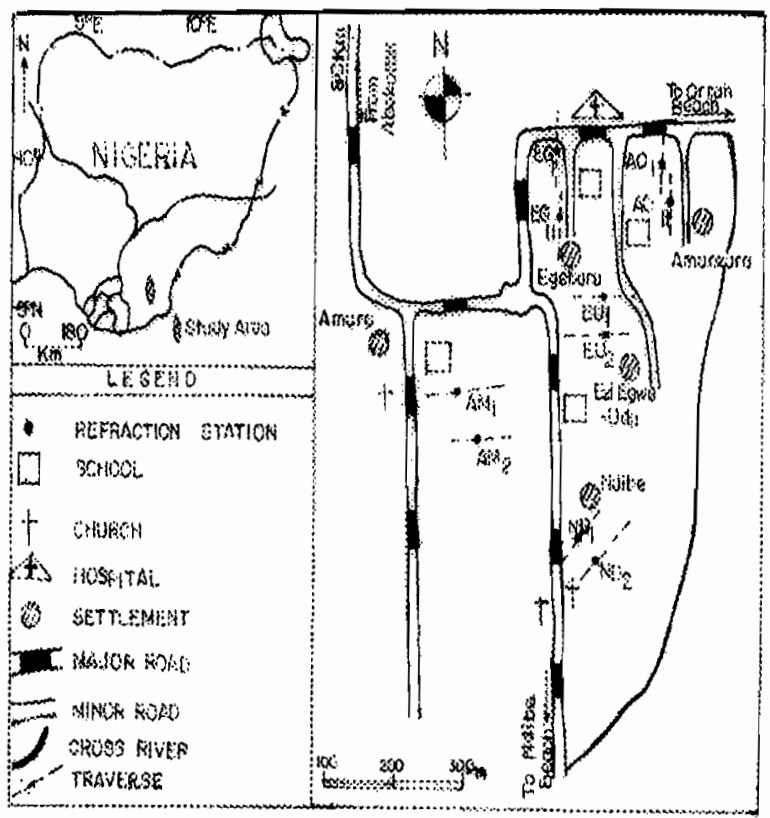

Fig. 1: Map of Nigeria showing location of study and seismic lines

The Albian Asu River Group comprises an uneven mixture of shales, sandstones, limestones and siltstones in some places. The sediments were deposited during the opening up of the Atlantic and the consequent separation of Africa and South America continents (Murat, 1970;

Nwachukwu, 1972). At the southern end, the sediments were later folded along northeastsouthwest direction forming the Abakiliki Anticlinorium (Murat, 1970).

The Eze Aku Formation is Turonian in age and it consists basically of flaggy, dark grey calcareous and non-calcareous shales, siltstones, sandstones sandy and shaly limestones and mudstones with frequent facie changes (Peters and Ekweozor, 1982 and Kogbe, 1976). Faults and igneous intrusion are common structural features in this unit.

The Nkporo Shale is the youngest unit of the cretaceous sequence and is Campanian Mastrichtian in age. Fissile dark-gray to black carbonaceous shale interbeded with thin ironstone beds and intercalated with sandstones, marls and gypsum are the major components of this formation (Murat, 1970). It directly underlies the Turonian Eze Aku Formation uncomformably.

\subsection{Field Methodology}

The survey was done between September, 2000 and December, 2001 and it involves establishing stations in each of the five major communities in Afikpo (Fig. 1). The five communities are Itim, Ozizza, Ohiasu, Ugwuegu and Nkpogoro. A total of ten sites were studied.

A portable 3-channel signal enhancement seismograph (MOD 579) which has a thermal printer DPU 411 type II was used in measuring the arrival times of the signals. The refracted signals were detected by low frequency $(10 \mathrm{~Hz}) \mathrm{s}$ and $\mathrm{p}$ geophones for $\mathrm{s}$ and $\mathrm{p}$ waves respectively.

Two traverses were surveyed in each of the five communities. No specific order was maintained in orienting a traverse but in all, four traverses were directed north-south, four in east-west and two in northeast-southwest directions. Each traverse was at least $50 \mathrm{~m}$ long with a geophone spacing of $5 \mathrm{~m}$. Inter station spacing varied from $800 \mathrm{~m}$ to $1000 \mathrm{~m}$

Some of the traverses were cleared for good visibility and cable security. The traverses were sited at locations that are free from road traffic noise and other sources of seismic noise.

The waves were mechanically generated.

The $p$ waves were generated by hitting a sledge-hammer perpendicular to a steel plate that is firmly coupled to the ground at about $5 \mathrm{~cm}$ from the surface. The $s$ waves were generated by hitting the same sledge-hammer horizontally on the same steel plate equally coupled firmly to the ground. 
Reverse profiles were undertaken to determine dipping angles and for better data interpretation

\subsection{Data Analysis, Results and Discussion}

The field data that comprises travel times and offsets were tabulated and graphs of travel times $T$ against offset $X$ plotted for each data points. Each data point is made up of $p$ and $s$ wave travel times (forward and reverse) and offsets (forward and reverse). They were all manually plotted on the same axes. A typical $\mathrm{T} X$ plot for the area is shown in Fig. 2.

Inverses of the slopes of all the linear portions of the oraphs were calculated. $P$ and $S$ waves

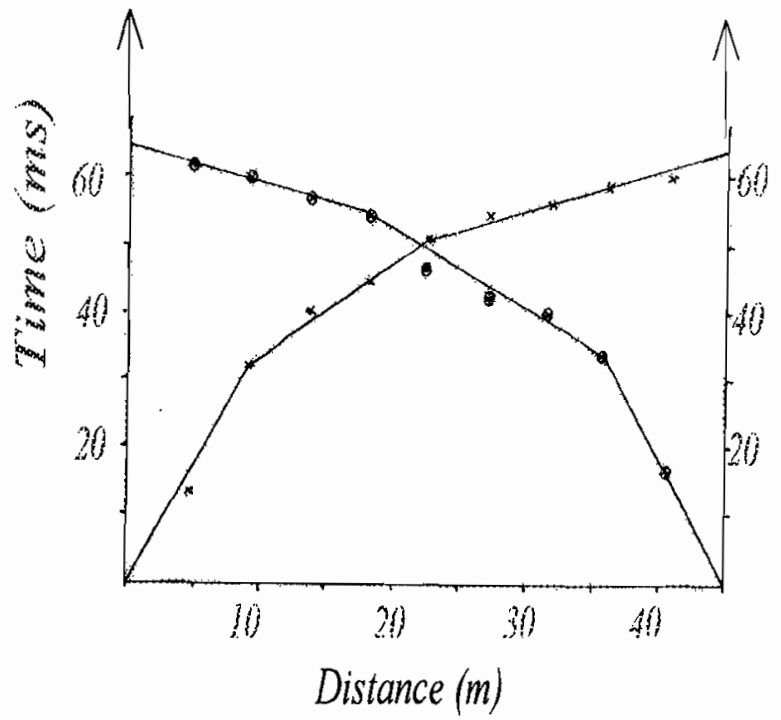

Fig.2:A typical $T-X$ plot from the area lithologic deductions made. Table 1 shows a summary of all the results obtained and probable lithologic deductions made.

velocities were inferred for both reverse and forward profiles. The velocities were determined and probable

Elastic parameters shear modulus, bulk modulus, poisson ratio, young modulus and lame constant were calculated. These calculations were done using average value of density of sedimentary rock that is $2,670 \mathrm{~kg} / \mathrm{m}^{3}$ (Gibbs, 1997). Table 2 gives a summary of all the results obtained.

The results show that shear modulus of the first layer at all the sites ranges from a minimum of $0.70 \times 10^{8} \mathrm{~N} / \mathrm{m}^{2}$ obtained at Nkpogoro community to a maximum of $7.00 \times 10^{8} \mathrm{~N} / \mathrm{m}^{2}$ obtained at $O z z i z a$ and $U g w u e g u$ communities with an average of $3.54 \times 10^{8} \mathrm{~N} / \mathrm{m}^{2}$. The second layer has a minimum shear modulus of $5.40 \times 10^{8} \mathrm{~N} / \mathrm{m}^{2}$ at Itim community and a maximum of $87.00 \times 10^{8} \mathrm{~N} / \mathrm{m}^{2}$ at $U g w u e g u$ community. The overall average is $33.74 \times 10^{8}$ $\mathrm{N} / \mathrm{m}^{2}$.

Bulk modulus of the first layer is minimum at Nkpogoro and Ohaisu communities $(\mathrm{k}=$ $0.20 \times 10^{\circ} \mathrm{N} / \mathrm{m}^{2}$ ) and maximum at Ozziza community $\left(\mathrm{k}=2.00 \times 10^{9} \mathrm{~N} / \mathrm{m}^{2}\right)$ with a mean of $0.72 \times 10^{9} \mathrm{~N} / \mathrm{m}^{2}$. The second layer has a minimum bulk modulus value of $1.20 \times 10^{9} \mathrm{~N} / \mathrm{m}^{2}$ at Itim community and a maximum of $45.00 \times 10^{9} \mathrm{~N} / \mathrm{m}^{2}$ at $O z z i z a$ community with an overall mean of $15.04 \times 10^{9} \mathrm{~N} / \mathrm{m}^{2}$

Table 1: Summary of results and probable lithologic deductions

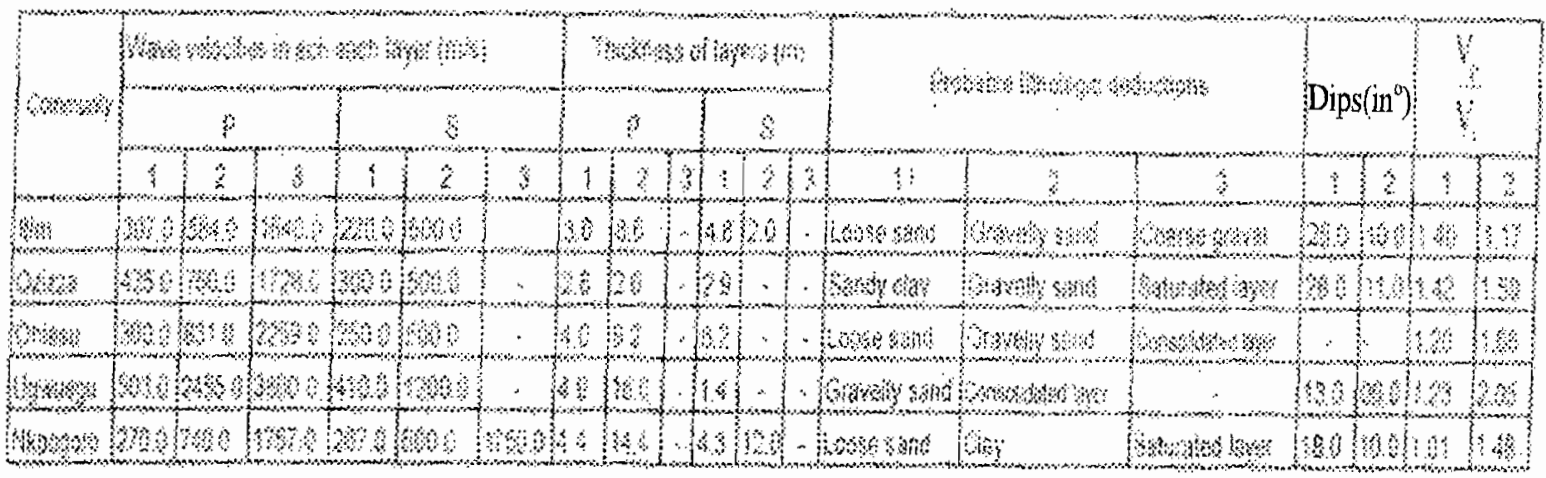


Young modulus of the first layer is minimum at Itim and Nkpogoro communities $(\mathrm{E}=$ $\left.0.30 \times 10^{9} \mathrm{~N} / \mathrm{m}^{2}\right)$ and maximum at Ozziza community $\left(E=2.00 \times 10^{9} \mathrm{~N} / \mathrm{m}^{2}\right)$ with a mean of $0.82 \times \times 10^{9} \mathrm{~N} / \mathrm{m}^{2}$. The second layer has a minimum of $1.40 \times 10^{9} \mathrm{~N} / \mathrm{m}^{2}$ obtained at Itim community and a maximum of $25.00 \times 10^{9} \mathrm{~N} / \mathrm{m}^{2}$ obtained at $U g w u e g u$ community with a mean of $9.54 \times 10^{9} \mathrm{~N} / \mathrm{m}^{2}$.

The first layer has minimum value of lame constant at Ozizza and Ugwuegu community $(\lambda)=-0.5 \times 10^{9} \mathrm{~N} / \mathrm{m}^{2}$ ) and a maximum of $9.0 \times 10^{9} \mathrm{~N} / \mathrm{m}^{2}$ at Ohiasu community with a mean of $2.52 \times 10^{9} \mathrm{~N} / \mathrm{m}^{2}$. A minimum value of $1.40 \times 10^{9} \mathrm{~N} / \mathrm{m}^{2}$ was obtained for the second layer at Itim and a maximum value of $88.00 \times 10^{9} \mathrm{~N} / \mathrm{m}^{2}$ was obtained at Ohiasu community with an overall average of $29.26 \times 10^{9} \mathrm{~N} / \mathrm{m}^{2}$.

Finally, poisson ratio for the first layer has a minimum value of 0.10 at Itim community and a maximum value of 0.23 at Ozziza community with as mean of 0.16 while the second layer has a minimum of 0.17 obtained at Ohaisu community and a maximum of 0.41 obtained at Ozziza community with a mean of 0.28

Details of these results are shown in Table 2 . The results indicate that at all sites, a large amount of force is needed before a unit area of the soils/rocks in the study area can be stressed. At all the sites investigated, $\mathrm{E}>\mathrm{k}>\mu$ which implies that the tangential force needed to stress a unit area of soils/rocks in the area is much larger than what is needed to compress it (Okwueze, 1991). The high values of point to the fact that the rocks/soils in the area can not be compressed easily. The values of the poisson ratio for both layers penetrated show that most of soils/rocks in the area are consolidated rocks except at the second layer of Ozziza community where it is poorly consolidated. These results qualify the soils/rocks in the area to be likely good foundation materials. This fact is also supported by the inverse relationship between V and ratio(Sheriff and Geldart, 1982).

Table 2. Summary of elastic constants

\begin{tabular}{|c|c|c|c|c|c|c|c|c|c|c|}
\hline \multirow{3}{*}{ Community } & \multicolumn{10}{|c|}{ Elastic constants of each layer } \\
\hline & \multicolumn{2}{|c|}{$\mu \times 10^{8}\left(\mathrm{Nm}^{2}\right)$} & \multicolumn{2}{|c|}{$\mathrm{KX} 108\left(\mathrm{~N}^{2} \mathrm{~m}^{2}\right)$} & \multicolumn{2}{|c|}{$\mathrm{EX} 10^{8}\left(\mathrm{~N}^{2}{ }^{2}\right)$} & \multicolumn{2}{|c|}{$\lambda \times 10^{8}\left(\mathrm{Nm}^{2}\right)$} & \multicolumn{2}{|c|}{ u } \\
\hline & 1 & 2 & 1 & 2 & 1 & 2 & 1 & 2 & 1 & 2 \\
\hline Itim & 1.30 & 05.40 & 0.30 & 01.20 & 0.30 & 01.40 & 1.30 & 01.40 & 0.10 & 0.19 \\
\hline Ozizza & 7.00 & 60.00 & 2,00 & 45.00 & 2.00 & 17.00 & 0.50 & 34.00 & 0.23 & 0.41 \\
\hline Ohiasu & 1.70 & 06.70 & 0.20 & 02.20 & 0.50 & 01.60 & 0.09 & 88.00 & 0.14 & 0.17 \\
\hline Ugmuegu & 7.00 & 87.00 & 0.90 & 23.00 & 1.00 & 25.00 & 0.50 & 21.00 & 0.13 & 0.30 \\
\hline Nkpogoro & 0.70 & 9.60 & 0.20 & 03.80 & 0.30 & 02.70 & 1.30 & 01.90 & 0.19 & 0.31 \\
\hline Average & 3.54 & 33.74 & 0.72 & 15.04 & 0.82 & 09.54 & 2.52 & 29.26 & 0.16 & 0.28 \\
\hline
\end{tabular}

\subsection{Conclusion}

The first and second layers of the soils in Afikpo have a mean shear modulus of $3.54 \times 10^{8}$ and $33.74 \times 10^{8} \mathrm{~N} / \mathrm{m}^{2}$, bulk modulus of $0.72 \times 10^{9}$ and $15.04 \times 10^{9} \mathrm{~N} / \mathrm{m}^{2}$, young modulus of $0.82 \times 10^{9}$ and $9.54 \times 10^{9} \mathrm{~N} / \mathrm{m}^{2}$, lame constant of $2.52 \times 10^{9}$ and $29.26 \times 10^{9} \mathrm{~N} / \mathrm{m}^{2}$ and poisson ratio of 0.16 and 0.28 . Soils/rocks in the area require a large amount of force before a unit area of it is stressed. The soils/rocks in the area are not only rigid but also well consolidated and so are suitable for engineering construction work. 
References

Dobrin, M. and Savit, C. H. (1988): Introduction to Geophysical Prospecting (4th ed.). McGraw-Hill Book Company, New York.

Domenico, S. N. (1977): Elastic Properties of Unconsolidated Porous Sand Reservoirs Geophysics 42: 1339-1368.

Gibbs, K. (1997): Fundamentals of Geophysics. Cambridge University Press, London.

Griffiths, D. and King, R. F. (1981): Applied Geophysics for Geologists and Engineers Pergamon Press, Oxford.

Kearey, P. and Brooks, M. (1991): An Introduction to Geophysical Prospecting (2nd ed.). Blackwell Scientific Publications, London, UK.

Kogbe, C. A. (1976): The Cretaceous and Paleocene Sediments of Southern Nigeria In: Geology of Nigeria (ed. C. A. Kogbe). Elizabethan Publ. Co.,
Lagos. 273-282.

Mesfin, D. and Moon, W. (1984): Seismic Approaches to Structural Studies of the Sudbury Basin. Geophysics, 49(10): 1675-1689.

Murat, R. C. (1970): Stratigraphy and Paleography of the Cretaceous and Lower Tertiary in Southern Nigeria. In: Dessauvagie, T. F. J. and Whiteman, A. J. (eds) African Geology. University of Ibadan Press, Ibadan, Nigeria, pp 251266.

Nwachukwu, S. O. (1972): The Tectonic Evolution of Southern Portion of the Benue Trough. Nigerian Geological Magazine, 109:411-419.

Okwueze, E. E. (1991): Shear Wave observation in Seismic Refraction Prospecting. Journal of Mining and Geology, 24(1\&2).

Okwueze, E. E. (1988): Mapping Bedrock Surface and Lithology with Seismic Refraction 